\title{
INTEGRATIVE MANAGEMENT OF COCOA AGROFORESTRY SYSTEMS: PROMOTING LONG-TERM ON-FARM DIVERSITY
}

\author{
M.E. Isaac ${ }^{1}$ and E. Dawoe ${ }^{2}$ \\ ${ }^{1}$ Department of Physical and Environmental Sciences and Department of Social Sciences, \\ International Development Studies, University of Toronto, Toronto, Canada \\ ${ }^{2}$ Technology Consultancy Centre, \\ Kwame Nkrumah University of Science and Technology, Kumasi, Ghana
}

\begin{abstract}
In cocoa (Theobroma cacao) agroforestry systems, upper canopy trees and food crops are frequently planted for shade, diversification of farm products, and improved soil fertility. As diversification remains a top priority for farm economic and environmental sustainability, system management plays a substantial role in farm diversity, requiring long-term analysis. We measured species richness dynamics in a chronosequence $(N=4)$ representing farms aged 2 to 25 years old in the western cocoa-growing region of Ghana, West Africa. Subsequently, we conducted farmer interviews to establish farming practices with regards to integration of non-cocoa species. After farm establishment, increases were recorded in non-cocoa and Simpson diversity index (for 2 years $=0.17 \pm 0.167$; for 15 years $=0.68 \pm 0.026$; for 25 years $=0.68 \pm 0.036$ ), but no changes were observed in crop richness. All participants interviewed managed supplementary species on their cocoa farms, with $92 \%$ of farmers purposefully establishing an upper canopy stratum. We discuss the use of principles from natural stand development for sustaining such diversity. Farmer managed crop re-initiation during farm maturation may promote higher diversity within an existing agroforestry framework.
\end{abstract}

Keywords: Understory re-initiation, Simpson diversity index, chronosequence

\section{INTRODUCTION}

Cocoa (Theobroma cacao L.), a tree crop of high economic importance, is commonly found in small-scale production (International Cocoa Organization [ICCO], 1997). Frequently, understory food crops and upper canopy trees are established on cocoa farms for consumption, additional income, minimization of risk through diversification, and provision of shade for cocoa plants (Beer et al., 1998; Duguma et al., 2001; Isaac et al., 2007). Hence, integration of crop production and upper canopy trees are management options during farm development. The use of multiple species within an agroforestry plantation system provides distinct structural and compositional diversity (Soto-Pinto et al., 2000; Duguma et al., 2001; Siebert, 2002). The maintenance of agroforestry diversity remains a top ecological and economic priority for farm sustainability as well as improves farm potential for adaptability to changing conditions (McNeely, 2004; McNeely and Schroth, 2006). As the farmer goal is for the most part profitability, advancement of economic diversi- 
fication also takes precedence (Asare, 2006). However, recent pressure in the Western Region of Ghana for higher cocoa production, reductions in available land and increased access to inorganic fertilizers have resulted in the removal of upper canopy and food crop species (Boni et al, 2004), presumably affecting overall species richness. Farmer initiated additions to species richness may have substantial effects in systems of low diversity; hence farmer management techniques influencing species composition and structural dynamics in small-holder cocoa production requires development and optimization of all components (Altieri, 1989; Duguma et al., 2001; Kindt et al., 2004).

Previous work suggests correlations between farm species diversity and farmer and/or household characteristics (Augusseau et al., 2006; Bobo et al., 2006). Static diversity often varies according to landscape type (natural forest, secondary forest, agroforest) (Oke and Odebiyi, 2007), with studies commonly indicating a need for re-introduction of forest species within an agriculture framework (Zapfeck et al., 2002; Kindt et al., 2004). However, inconclusive evidence remains on the long-term dynamics of farm diversity. Within the pre-existing agroforestry framework, identification of appropriate times for farmer manipulated tree and/or crop integration may have greater success for sustained farm diversity (Augusseau et al., 2006).

By examining non-cocoa species in a chronosequence, this study investigates the evolution of farm diversity as well as existing management models. Our approach was to measure species richness and structural diversity during a 25year period using a chronosequence, where farms of similar character but of varying ages concurrently represent a long-term time scale. Linking species diversity to farmer practices during a farms life cycle provides currently scarce information on farm diversity dynamics. We discuss the use of principles from natural stand development to provide a potential framework for sustaining such diversity.

\section{MATERIALS AND METHODS}

This study was conducted in Ghana, West Af- rica in the moist semi-deciduous tropical cocoa growing district, Sefwi Wiawso $\left(06^{\circ} 12^{\prime} \mathrm{N}\right.$ and $02^{\circ} 29^{\prime} \mathrm{W}$ ) in the Western Region. The region has an annual mean precipitation of approximately 1,461 mm (1964-2001), an average temperature of $26^{\circ} \mathrm{C}(2001)$, a population of approximately 149,000 in 60 different villages (based on the 2000 housing and population census) with over $80 \%$ of the population undertaking agriculture as the dominant economic activity (Boni et al., 2004).

Twelve cultivated field sites were selected and sites were blocked into four. The chronosequence consisted of three treatments, farms established 25 years ago $(\mathrm{N}=4), 15$ years ago $(\mathrm{N}=4)$ and 2 years ago $(\mathrm{N}=4)$. These preselected treatments represent operationalized phases of cocoa farm development, as described by farmers: planting and establishment phase ( 2 years), productive phase (15 years) and mature phase (25 years). Site selection criteria for the chronosequence was based on similarity of soil type (Rhodic Ferrasols), past management (converted secondary forest), and climate (temperature/precipitation) in the region. Sites selected surrounded four villages, Nipa Tirim, Bosomoiso, Aboprey and Sui, each approximately $10 \mathrm{~km}$ from the main town of Sefwi Wiawso. Socio-economic farm characteristics were investigated and accepted as consistent between sites: distance to market in nearest town (Sefwi Wiawso), village size and size of farms.

Stem density for shade and crop plants at 2, 15 and 25 year-old sites were measured using 25 $\mathrm{m} \times 25 \mathrm{~m}$ plots $\left(625 \mathrm{~m}^{2}\right)$. Plots were randomly selected within each site. Species richness and stem density was counted and recorded in each plot per treatment per block. Individual plants above the cocoa canopy with DBH greater than $5 \mathrm{~cm}$ were included in the tree component. All established understory crops were included in the crop component. The Simpson Index of Diversity was calculated to measure both richness and distribution of population diversity by the equation (Krebs, 1999): 
Simpson's Index $=1-\mathrm{D}$, where $\mathrm{D}=\Sigma\left(\mathrm{P}^{2}\right)$ and $P=\frac{\text { No. of individuals of species } i}{\text { Total No. of individuals of all species }}$

Simpson's index, stem density and species richness were analyzed using Proc GLM in SAS version 8.0. Significant results were subsequently assessed by a Tukey's test (HSD). A Type I error rate was set at 0.05 for all statistical tests.

Employing an unstructured interview technique and focus groups, questions pertaining to the nature of agroforestry management, site descriptions and cropping schedules were conducted. A questionnaire was then developed to address key issues defined in these preliminary unstructured interviews. Questions were guided by selected topics while remaining flexible enough to include other topics of interest to the farmer. Questionnaires involved three parts: personal details of respondents and their household characteristics; farm management practices, specifically, management of crops and trees; and local knowledge on the role of trees in their farming systems. The questionnaires were pre-tested by the authors in one of the project communities which resulted in modification of certain terminologies to increase accuracy of the data collection process. Prior to the administration of questionnaires, an enumerator was briefed on research objectives and given a $1 / 2$-day training on the interpretation of ques- tions into local dialects as well as the art of interviewing. The sample unit was the farm household and questionnaires were offered verbally to a random sample of 50 participants.

\section{RESULTS}

Dynamics of species richness and composition Species richness data illustrated a significant increase $(\mathrm{F}=15.80 ; P=0.0011)$ in the number of tree species over the chronosequence after farm establishment, however crop species richness showed no change $(\mathrm{F}=1.48 ; P=0.2790)$ after farm establishment ( 2 years) (Fig. 1). The Simpson diversity index values (Table 1) showed no significant difference in crop diversity at the three farm ages $(\mathrm{F}=2.35 ; P=$ 0.151). However, the Simpson diversity index for the tree component was significantly less $(\mathrm{F}$ $=11.26 ; P=0.010)$ at 2 years after land conversion $(0.17 \pm 0.167)$ as compared to 15 and 25 years after conversion $(0.063 \pm 0.026$ and $0.68 \pm 0.036$ respectively), with a dramatic change in tree diversity as cocoa farms aged. Overall tree stem density significantly increased $(\mathrm{F}=21.00 ; P=0.0001)$ with farm age, where as individual crop density, although varying, did not change with time (Table 1).

Table 1: Simpson diversity index values ( \pm standard error) and mean stem density (individuals per area) values ( \pm standard error) for both crop (under cocoa canopy) and tree (above cocoa canopy) component for young ( 2 years), established (15 years) and mature (25 years) cocoa farms in Sefwi Wiawso District, Ghana $(n=4)$

\begin{tabular}{ccccc}
\hline \multirow{2}{*}{$\begin{array}{c}\text { Time since land } \\
\text { conversion }\end{array}$} & \multicolumn{2}{c}{$\begin{array}{c}\text { Simpson diversity } \\
\text { index }\end{array}$} & \multicolumn{2}{c}{ Stem density } \\
& Crop & Tree & Crop & Tree \\
\hline 2 years & $0.65 \pm 0.081 \mathrm{a}$ & $0.17 \pm 0.167 \mathrm{a}$ & $56 \pm 10.3 \mathrm{a}$ & $1.0 \pm 0.00 \mathrm{a}$ \\
15 years & $0.47 \pm 0.119 \mathrm{a}$ & $0.63 \pm 0.026 \mathrm{~b}$ & $52 \pm 12.0 \mathrm{a}$ & $3.5 \pm 0.39 \mathrm{~b}$ \\
25 years & $0.27 \pm 0.164 \mathrm{a}$ & $0.68 \pm 0.036 \mathrm{~b}$ & $32 \pm 9.2 \mathrm{a}$ & $3.9 \pm 0.46 \mathrm{~b}$ \\
\hline
\end{tabular}

Means within a column followed by the same letter are not significantly different at $P<0.05$, according to Tukey's (HSD) test. 


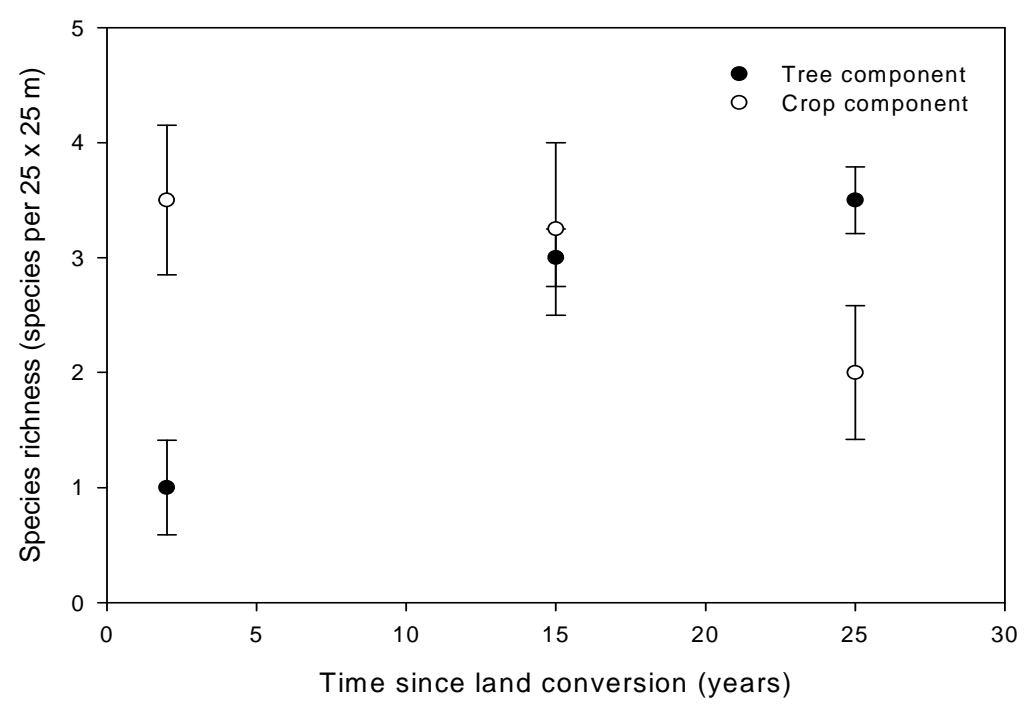

Fig. 1: Mean ( \pm standard error) tree and crop species richness (species per $25 \times 25 \mathrm{~m}$ ) at 2,15 and 25 years since farm establishment $(N=4)$.

Farmer demographics and management practices

Seventy-six percent of participants were male and $24 \%$ female, ranging from young, new farmers to elderly, experienced farmers. Respondent age ranged from 17 to over 78 years old with the majority of interviewees in the 4150 year old category. Farm size was variable, however typically ranging from $1 / 2$ to 4 ha. All farmers interviewed had more than one age of cocoa farm, with $72 \%$ of farmers having between one and ten different ages under their management, and the remaining greater than ten different farm ages under management, suggesting that farmers were continually establishing farms. Ownership of land fell into six categories: farmer (68\%), father of farmer $(8 \%)$, mother of farmer $(4 \%)$, chief $(4 \%)$, shared $(14 \%)$ or husband of farmer $(2 \%)$. In total, $82 \%$ of the farms were owned by either the farmer or a close relative. All farmers interviewed had supplementary species in addition to cocoa on their farms (Table 2).

Although indigenous native tree species were selectively retained during land preparation, little deliberate planting of indigenous tree spe- cies occurred. However, fruit trees were purposefully planted ( $92 \%$ of farmers), functioning as initial shade trees for cocoa seedlings. These species included but were not limited to avocado (Persea americana L.) and oil palms (Elaeis guineenis Jacq.). Reasons given for retaining or planting supplementary trees and crops within cocoa plantations were varied, with farmers identifying shade provision $(51 \%)$ as a high priority. Income (16\%) also held high importance when considering additions to farm species composition. Few farmers $(5 \%)$ cited future timber value as rationale for maintaining trees on farms. Thirteen percent of farmers mentioned food production as the driving motivation for planting non-cocoa species, thus establishing a third stratum of understory crops.

Management techniques for cocoa farms were comparable between participants with minimal variation and little mention of altering practices during the farm life cycle. Few farmers $(16 \%)$ in the Sefwi Wiawso communities changed their land preparation methods over time and if so, usually converting from burning residues to a no-burn system. However, $74 \%$ of farmers still conducted the common preparation process 
Table 2. Total species (scientific and local terminology), functional group (crop or tree) and origin (for tree component) for each chronosequence phase in Sefwi Wiawso District, Ghana

\begin{tabular}{|c|c|c|c|}
\hline $\begin{array}{c}\begin{array}{c}\text { Treatment } \\
\text { (years) }\end{array} \\
\end{array}$ & Scientific Name & Local/common name & Functional group \\
\hline \multicolumn{4}{|l|}{2 years } \\
\hline & Musa spp. & Bordie & Shade \\
\hline & Colocasia esculenta & Mankani & Crop \\
\hline & Manihot esculenta & Bankyi & Shade \\
\hline & Solanum melongena & Garden eggs & Crop \\
\hline & Ananas comosus & Pineapple & Crop \\
\hline & Elaeis guineensis & Abe & Native fruit tree \\
\hline & Persea americana & Pear & Exotic fruit tree \\
\hline & Newbouldia laevis & Susumesa & Native tree \\
\hline \multicolumn{4}{|l|}{15 years } \\
\hline & Colocasia esculenta & Mankani & Crop \\
\hline & Dioscorea spp. & 'Cocoa-ase' Bayire & Crop \\
\hline & Ananas comosus & Pineapple & Crop \\
\hline & Elaeis guineensis & Abe & Native fruit tree \\
\hline & Persea Americana & Pear & Exotic fruit tree \\
\hline & Milicia excelsa & Odum & Native tree \\
\hline & Newbouldia laevis & Susumesa & Native tree \\
\hline & Terminalia superba & Ofram & Native tree \\
\hline \multicolumn{4}{|l|}{25 years } \\
\hline & Colocasia esculenta & Mankani & Crop \\
\hline & Dioscorea spp. & 'Cocoa-ase' Bayire & Crop \\
\hline & Ananas comosus & Pineapple & Crop \\
\hline & Persea Americana & Pear & Exotic fruit tree \\
\hline & Newbouldia laevis & Susumesa & Native tree \\
\hline & Terminalia superba & Ofram & Native tree \\
\hline & Ficus exasperata & Nyankyerene & Native tree \\
\hline & Ceiba pentandra & Onyina & Exotic tree \\
\hline & Celtis milbraedii & Esa & Exotic tree \\
\hline
\end{tabular}

of burning debris, weeding and planting cocoa seedlings.

\section{DISCUSSION}

\section{Long-term farm diversity}

Although conflicting reports on trends in agroforestry diversity exist (Soto-Pinto et al., 2000; Asare, 2006; McNeeley and Schroth, 2006), as observed in this study, once farms are established, tree species composition peaked in the production and mature phase of farm development (Fig. 1; Table 1). Stable crop richness may simply be a result of decreased emphasis on crop production, where annual crops are only used for income and consumption during the initial establishment phase of the cocoa crop. Consequently, the majority of farmers phased out food crops by three to five years after farm establishment. As the magnitude of deforestation intensifies within this region (Boni et al., 2004), cocoa farms are more often than not established from fallow, resulting in a reduction of traditional upper canopy trees and timber species on new farms with more emphasis on fruit trees (Oke and Odeyibi, 2007; Isaac et al., 2008). Promotion of indigenous tree integration has proved successful in other regions and support of this practice in Ghana may 
enhance purposeful planting of native tree species (Leakey and Tchoundjeu, 2001). However, currently avocadoes, oil palms, and plantains increasingly act as the principal shade trees for growing cocoa seedlings in early growth.

\section{Linking farmer practices and farm diversity} Diversity is dependent upon particular management practices (Perfecto et al., 2005; Augusseau et al., 2006; Oke and Odebiyi, 2007; Isaac et al., 2008) and our findings of temporal variability in composition and structure in this region was supported by farmer interviews in so far as participants suggested both ecological advantages and disadvantages to establishing an understory and upper canopy. Interviews indicated that a particular balance was required in the density of upper canopy trees and crops, such that too many or too few individuals resulted in negative impacts on farm health and cocoa production. Farmers in the region acknowledged placing less emphasis on food crops once the cocoa plants were established and producing and noted removing a tree if the tree was not providing any financial or ecological benefit. Consequently, over time, production emphasis was placed on the cocoa stratum instead of the upper canopy and understory crop strata.

Agreement between policy, on-farm practices and extension information is recommended for improved farm management and subsequent biodiversity (Asare, 2006). However, another contribution may be found in the field of silviculture, suggesting improvements to long-term diversity rooted in management principles that mimic natural stands (Bergeron and Harvey 1997; Kelty, 2006). Conceivably, species composition within this agroforestry system emulates similar patterns of natural stand development. Stages of stand initiation, stem exclusion and understory re-initiation, although simplified, are an appropriate model for early growth in even-aged stands (Franklin et al., 2002). Over the 25 year chronosequence, this agroforestry system does not simply reflect a static stand structure and composition (Kelty, 2000), but an analogous sequence of partial stand development (Fig. 1). Two years after farm establishment represents a stand initiation phase, followed by a stem exclusion phase (15 years), when the cocoa canopy closes and understory vegetation is eliminated from the system through predominantly farmer managed practices. However, in natural stands, understory re -initiation by natural recruitment of volunteers follows as gap dynamics commence and resources are sufficient to establish under canopy growth (Oliver and Larson, 1996). In response to our findings of stable crop richness over time, this latter phase of natural stand development may be promoted in mature cocoa agroforest management to increase crop production. Presumably, natural gap dynamics could be utilized or imitated to launch farmer initiated and controlled understory crop growth into the system. It however needs to be mentioned that canopy gaps act as spots for undesirable weed growth, and cocoa mirids (caspids) often aggregate in "pockets" created by breaks in cocoa shade canopies (Padi and Owusu, 1998). Therefore the use of natural gap dynamics for understory crop growth should be conducted in such a manner as to minimize these potential adverse effects through the adoption of appropriate management practices. Using a natural stand model to guide agroforest development, in concert with the pre-existing farmer management framework, may result in more successful longterm farm diversity, food security and sustainability.

\section{CONCLUSIONS}

On-farm tree stratum diversity increased over time, paralleled by stable crop richness. Comparable to understory re-initiation in natural stands, farmer managed integration of food crops during farm maturation may be modeled from natural stand dynamics, subsequently improving both compositional and structural diversity. Amid prevalent monoculture systems and reduced on-farm diversification, application of this framework may lead to sustained food production and improved farm diversity. 


\section{ACKNOWLEDGEMENTS}

We would like to thank participating farmers in the Sefwi Wiawso District, Ghana. We are also grateful to the Faculty of Renewable Natural Resources, Kwame Nkrumah University of Science and Technology, Ghana, for research support. We would like to acknowledge the constructive comments by an anonymous journal reviewer.

\section{REFERENCES}

Altieri, M.A. (1989). Rethinking crop genetic resource conservation: A view from the South. Conservation Biology 3: 77-79.

Asare, R. (2006). A review on cocoa agroforestry as a means for biodiversity conservation. World Cocoa Foundation Partnership Conference, Brussels. 16 pp.

Augusseau, X., Nikiema, P, and Torquebiau, E. (2006). Tree biodiversity, land dynamics and farmers' strategies on the agricultural frontier of southwestern Burkina Faso. Biodiversity and Conservation 15: 613630.

Beer, J., Muschler, R., Kass, D. and Somarriba, E. (1998). Shade management in coffee and cacao plantations. Agroforestry Systems 38: 139-164.

Bergeron, Y. and Harvey, B. (1997). Basing silviculture on natural ecosystem dynamics: an approach applied to the southern boreal mixedwood forest of Quebec. Forest Ecology Management 92: 235-242.

Bobo, K.S., Waltert, M., Sainge, M. N., Njokagbor, J., Fermon, H. and Muhlenberg, M. (2006). From forest to farmland: species richness patterns of trees and understorey plants along a gradient of forest conversion in Southwestern Cameroon. Biodiversity and Conservation 15: 40974117.

Boni, S., Nuhu, R. I., Reuter, F. and Da Re, G. (2004). Anthropological, Environmental and Soils Assessment of the Sefwi Wiawso District, Ghana. Ricerca e Cooperazione, European Commission, Italy. 202pp.
Duguma, B., Gockowski, J. and Bakala, J. (2001). Smallholder Cacao (Theobroma cacao Linn.) cultivation in agroforestry systems of West and Central Africa: challenges and opportunities. Agroforestry Systems 51: 177-188.

Franklin, J.F., Spies, T.A., Van Pelt, R., Carey, A.B., Thornburgh, D.A., Berg, D.R., Lindenmayer, D.B., Hermon, M.E., Keeton, W.S., Shaw, D.C., Bible, K. and Chen, J. (2002). Disturbances and structural development of natural forest ecosystems with silvicultural implications, using Douglasfir forests as an example. Forest Ecology and Management 155: 399-425.

International Cacao Organization (ICCO) (1997). Quarterly Bulletin of Cacao Statistics, June. London, England: International Cacao Organization.

Isaac, M.E., Dawoe, E. and Sieciechowicz, K. (2008). Assessing localized knowledge use in agroforestry management with cognitive maps. Environmental Management, in press.

Isaac, M.E., Timmer, V.R. and Quashie-Sam, J. (2007). Shade tree effects in an 8-year-old cocoa agroforestry system: Biomass and nutrient diagnosis of Theobroma cacao by vector analysis. Nutrient Cycling in Agroecosystems 78: 155-165.

Kelty, M.J. (2006). The role of species mixtures in plantation forestry. Forest Ecology and Management 233: 195-204.

Kelty, M.J. (2000). Species interactions, stand structure and productivity in agroforestry systems. In Silvicultural Basis for Agroforestry Systems, eds. M.S. Ashton and F. Montagnini. pp. 183-205. Florida, USA: CRC Press LLC.

Kindt, R., Simons, A.J. and P. Van Damme, P. (2004). Do Farm Characteristics Explain Differences in Tree Species Diversity among Western Kenyan Farms? Agroforestry Systems 63: 63-74. 
Krebs, C.J. (1999). Ecological Methodology. Addison-Wesley, California .

Leakey, R.R.B. and Tchoundjeu, Z. (2001). Diversification of tree crops: domestication of companion crops for poverty reductions and environmental services. Experimental Agriculture 37: 279-296.

McNeely, J.A. (2004). Nature vs. nurture: managing relationships between forests, agroforestry and wild biodiversity. Agroforestry Systems 61: 155-165.

McNeely, J.A. and Schroth, G. (2006). Agroforestry and biodiversity conservation traditional practices, present dynamics, and lessons for the future. Biodiversity and Conservation 15: 549-554.

Oke, D.O. and Odebiyi, K.A. (2007). Traditional cocoa-based agroforestry and forest species conservation in Ondo State, Nigeria. Agriculture, Ecosystems and Environment, in press.

Oliver, C.D. and Larson, B.C. (1996). Forest Stand Dynamics. New York, USA: John Wiley and Sons.

Padi, B. and Owusu, G.K. (1998). Towards an integrated pest management for sustainable cocoa production in Ghana. Accessed $15^{\mathrm{TH}}$ March 2007 from http://nationalzoo.si.edu/ ConservationAndScience/MigratoryBirds/ Research/Cacao/padi.cfm.
Perfecto, I., Vandermeer, J., Mas, A. and Pinto, L.S. (2005). Biodiversity, yield, and shade coffee certification. Ecological Economics 54: 435-446.

Siebert, S.F. (2002). From shade- to sun-grown perennial crops in Sulawesi, Indonesia: Implications for biodiversity conservation and soil fertility. Biodiversity and Conservation 11: 1889-1902.

Soto-Pinto, L., Perfecto, I., Castillo-Hernandez, J. and Caballero-Nieto, J. (2000). Shade effect on coffee production at the Northern Tzeltal zone of the state of Chiapas, Mexico. Agriculture, Ecosystems and Environment 90: 61-69.

Zapfack, L., Engwald, S., Sonke, B., Achoundong, G. and Madong, B.A. (2002). The impact of land conversion on plant biodiversity in the forest zone of Cameroon. Biodiversity and Conservation 11: 20472061. 